\title{
実験的高コレステロール血に関する研究 (III)
}

Experimental Studies on Hypercholesteremia (III)

飽和脂肪酸拱取による白ネズミ血清コレステロール量の変動について

The change in the amount of serum cholesterol in rast

by feeding saturated fatty acid

(昭和 43 年 7 月 4 日受理)

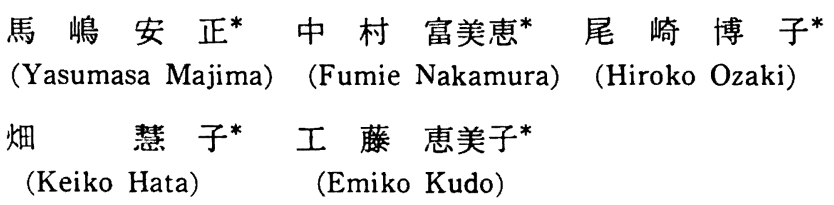

Rats were fed with the diet of various saturated fatty acid and saturated triglycerides for 8 weeks and the effect on their serum cholesterol was studied.

When stearic, palmitic, myristic, lauric, capric and caproic acids, and tristearin, tripalmitin, trimyristin, trilaurin, tricaprin and tricapron were fed, the increase of serum cholesterol was observed in the same rate of all, as compared with that of linoleic-oleic acids (1:5) group.

和和脂肪酸あるいは不飽和脂肪酸の多いラート，動物 油を摂ると血清コレステロールが增量したりやー3，動脈 硬化症を起ず)ことは既に知られている。しかし個々の 稳和脂肪酸によってそれらに差異があるかどらかに関 する知見は少ないら。そこで白ネズミを用いて種々の跑 和脂肪酸を脂肪酸とトリグリ七リドの形で長期間摂取さ せ，血清コレステロールの增量度を比較して見ること にした。

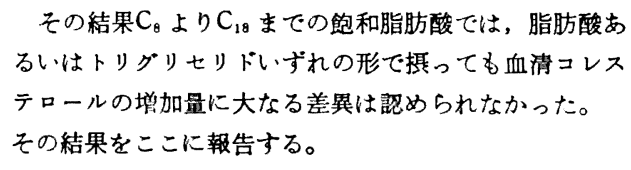

その結果 $\mathrm{C}_{8}$ より $\mathrm{C}_{18}$ までの飽和脂肪酸では，脂肪酸あ るいはトリグリセリドいずれの形で摂っても血清コレス テロールの增加量に大なる差異は訆められなかった。 その結果をここに報告する。

\section{実験材料および方法}

約85gの白ネ゙゙ミ（す）2〜6匹を14群に分け各群に ステフリン酸, パルミチン酸, ミリスチン酸, ラウリン

\begin{tabular}{|c|c|c|c|}
\hline 脱脂カゼイン & $14 \mathrm{~g}$ & ビタミン $\mathrm{B}_{12}$ & $0.002 \mathrm{mg}$ \\
\hline 愿榶 & $41 \mathrm{~g}$ & ニコチン酸 & $20 \mathrm{mg}$ \\
\hline 檓粉 & $41 \mathrm{~g}$ & 塩酸チアミン & $2 \mathrm{mg}$ \\
\hline マッカラム塩 & $4 \mathrm{~g}$ & リボフラビン & $3 \mathrm{mg}$ \\
\hline ビタミンA & 3,000 I. U. & 塩酸ピリドキシン & $3 \mathrm{mg}$ \\
\hline ビタミンD & 400 I. U. & パントテン酸カルシウム & $1 \mathrm{mg}$ \\
\hline フスコルビン酸 & $75 \mathrm{mg}$ & ピタミン $\mathrm{K}$ & $0.4 \mathrm{mg}$ \\
\hline 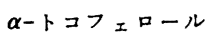 & $2 \mathrm{mg}$ & 塩化コリン & $0.1 \mathrm{~g}$ \\
\hline
\end{tabular}

* 武藏野女子大学 
酸, カプリン酸,カプロン酸, オレイン酸十リノール酸 (5：1）トリステフリン,トリパルミチン, トリミリ スチン,トリラウリン, トリカプリン, トリカプロンお よびオレフ油を次の基本食（脱脂食）に各10\%添加し保 温箱中 $\left(20 \sim 30^{\circ} \mathrm{C}\right)$ で 8 週間飼養した後血清総コレス テロール量を Zak法到で測定した。添加脂質の脂肪酸は ガスクロマトグラフィークによって純度を確認した。 （比較的純度は良く $90 \%$ 以上であった。ただしオレイン 酸は䄪 $80 \%$ )

実 験 成 績

白ネズミに種々の飽和脂肪酸を摸取させ 8 週後の体重
および血清総コレステロール量は表 1 のよ5であった。 体重は各群とも大なる差はなく比較的よく增加した。た だしカプリール酸群は隇少し全部死亡したので記城を中 此した。血清総コレステロール量は対照のオレイン酸十 リノール酸 (5:1) 群に比べて皆同様約 2 倍增加し, 增加量の差は認められなかった。

同様種々の餙和脂肪酸トリグリセリドを摄取させ 8 週 後の結果は表 2 のよであった。

体重は表 1 同棁大差なく增加した。たたしトリカプリ ールは隇少し全部死亡したので記栈を中此した。血清総 コレステロール是も表 1 同様対照のオレフ油群に比べて

表 1 飽和脂肪酸を飼料に10\%添加して白ネズミ（合）を 8 週間飼着したときの血消コレステロール量

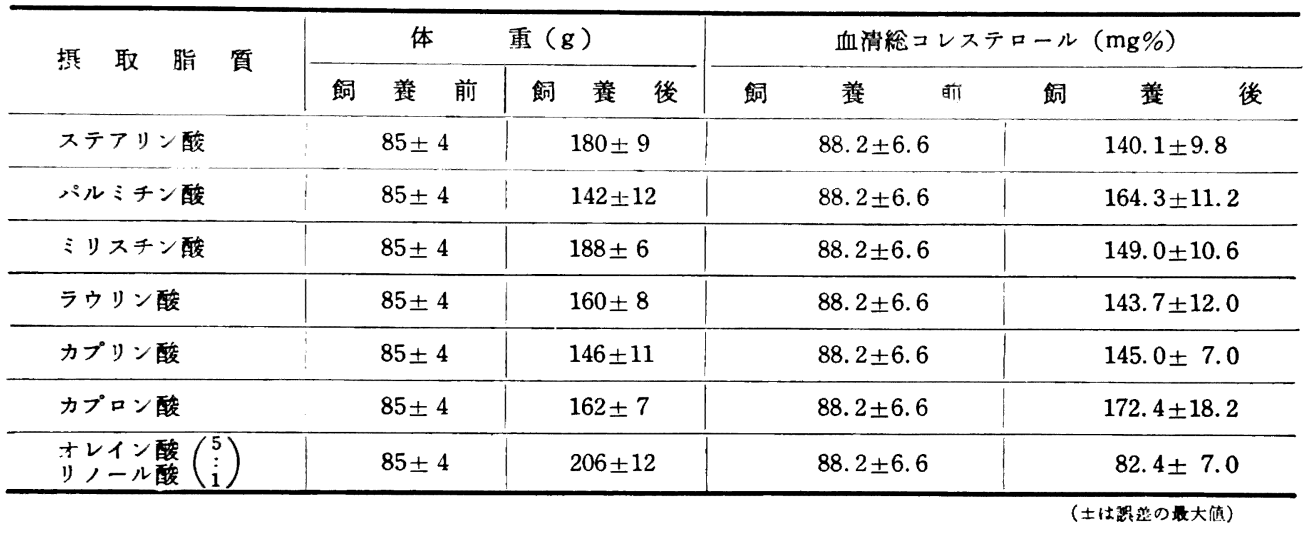

表 2 飼和脂肪酸トリグリセリドを飼料に10\%添加して白ネズミ（古）を 8 週間飼䉵したときの 血清コレステロール量

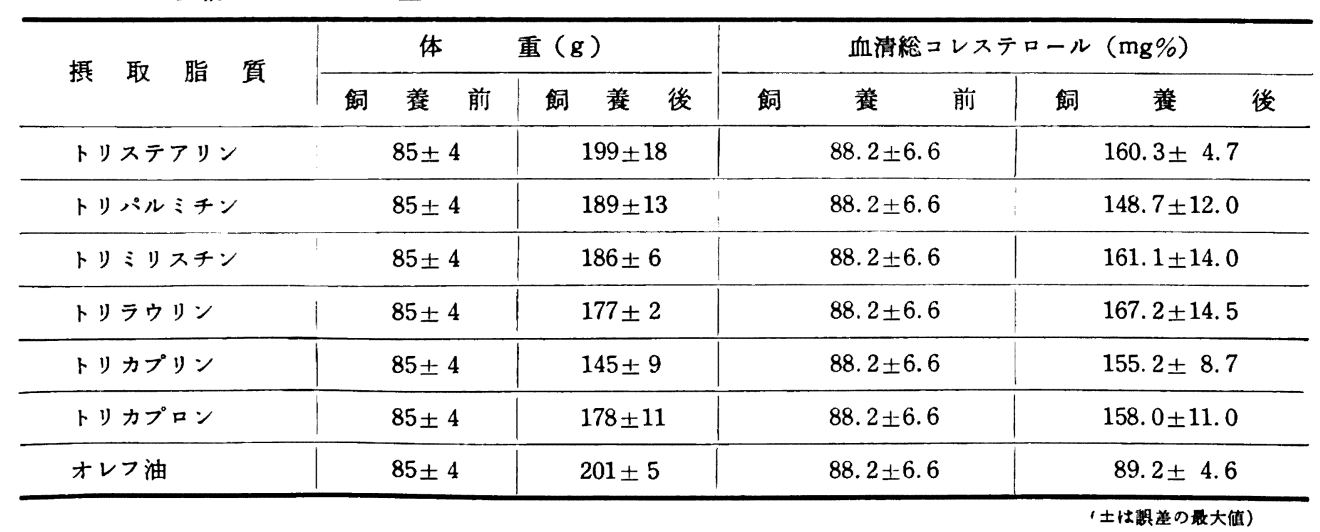


皆約 2 倍增加し，增加量の羑は認められなかった。

総括

幼若白ネズミに種々の渞和脂肪酸を脂肪酸あるいは卜 リグリセリドの形で飼料に10\%ずつ添加して 8 週間飼養 し血清コレステロール增加量を比較した。その結果 $\mathrm{C}_{8}$

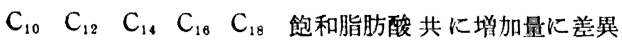
は割められなかった。

\section{文献}

1) Hildreth, E. A., Mellinkoff, S. M., Blair, G. M. and Hildreth, D. M. : Ciruculation, 3, 641 (1951)

2) Hardinge, M. G. and Stare, F. T. : Am. J. clin. Nutrition, 2, 83 (1954)

3 ) Wissler, R. W., Collins, J. L., Schroeder, M. and Soules, K. : Federation Proc., 12, 407 (1953)

4) Hartroft, W. S. and Thomas, W. A. : J. Am, Med. Assoc. 164, (1957)

5 ) Renaud. S., Allard, C and Latour, J. G. : J. Nutrition, 90, 433 (1966)

6) Zak, B. etal, : Am. J. clin. Path., 24, 1307(1954)

7) James, A. T. etal, : Lancet, 1, 705 (1957)

\section{高脂肪, コレステリン食を投与した成熟雄ラットにおける各種無機質の屎中排泄におよほす カルシウムとヒタミン $\mathrm{D}_{3}$ の影零}

生後 400 日の体重約 $500 \mathrm{~g}$ の成熟占ラットに高脂肺 (18 $\%)$,コレステリン ( $2 \%)$ 食を与え, 飼料中の $\mathrm{Ca} レ$ ベ ルを $0.08 \%, 1.2 \%$ と変えたとき，さらにビタミン $\mathrm{D}_{3}(25$ I. U./g diet）を添加したときの屎中への $\mathrm{Pb}, \mathrm{Ni}, \mathrm{Cu}$, $\mathrm{Cd}, \mathrm{Cr}, \mathrm{Fe}, \mathrm{Mn}, \mathrm{Zn}, \mathrm{Co}, \mathrm{Mg}$ の排泄様相を観察した。 Caレベルを0.08\%から1.2\%にあげた時, 上記のミネ ラルの屎中排泄は增加した。

さらにビタミン $\mathrm{D}_{3}$ を添加したときは，Ca レベルが 高い群ではCd, Mg の排泄增が見られるが， $\mathrm{Pb}, \mathrm{Mn}$, $\mathrm{Zn}, \mathrm{Co}, \mathrm{Ni}$ ，の排泄增は見られない。

ビタミン $\mathrm{D}_{3}$ 添加の有無にかかからず飼料中 Ca レベル の高い時は $\mathrm{Cu}, \mathrm{Fe}, \mathrm{Mn}, \mathrm{Mg} \mathrm{Zn}$ などの生体に必要な
ミネラルの排泄が多くなるので，Ca レベルを上げると きはこれらのミネラル投与量を上げる必要があろう。 また Ca レベルの高いとき，血清中のリポイドが低下

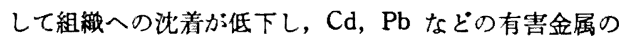
果中排泄增加がみられた。

Effect of Calcium and Vitamin $\mathrm{D}_{3}$ upon the Fecal Excretion of some Metals in the Mature Male Rat fed a High Fat, Cholesterol Diet.

A. I. Fleschman, H. Yacowitz, T. Hayton and M. L. Bierenbaum: J. Nutr. 95, 19-22 (1968) 